\title{
CERTAIN ASPECTS OF EU, AUSTRIAN AND HUNGARIAN LAW IN CONNECTION WITH INHERITANCE OF BUSINESS SHARES
}

\author{
Dr. János Dúl, PhD, Assistant Research Fellow \\ National University of Public Service, Faculty of Science of Public \\ Governance and Administration \\ Üllői Street 82, Budapest,Hungary \\ dul.janos@uni-nke.hu
}

\begin{abstract}
The paper has three sections. First of all, the legal bases of Regulation (EU) No 650/2012 of the European Parliament and of the Council of 4 July 2012 on jurisdiction, applicable law, recognition and enforcement of decisions and acceptance and enforcement of authentic instruments in matters of succession and on the creation of a European Certificate of Succession are discussed, because this regulation shall be directly applicable in the Member States of European Union in accordance with the Treaties. There are several issues that fall outside the scope of the regulation, for example questions governed by the law of companies, such as clauses in the memorandum of association of companies, which determine what will happen to the shares upon the death of the members. From the point of view of Hungarian law, it is a matter of company law to talk about the inheritability of business shares in each type of companies.

The second part of the paper is about general rules in company law regarding inheritance of business shares and in the third part family firms are discussed. Writing about these is common in Austrian legal literature; in connection with these, succession in family firms is a significant topic. In Hungarian legal literature the term family firm is rarely found, but the usage and content of term "family firm" cannot be neglected because of their role in economy.
\end{abstract}

Keywords: inheritance law, company law, business shares, Succession Regulation, family firms

\section{INTRODUCTION}

This paper has three sections, those are similar to concentric circles: in the first part, we discuss the legal bases of Regulation (EU) No 650/2012 ${ }^{1}$ as a general

This paper was the presented at the conference "Accomplishments, aspects and perspectives - inheritance law in the EU". 15th anniversary of Inheritance Act of the Republic of Croatia, 2003 - 2018 at the Faculty of Law, J.J. Strossmayer University of Osijek on 26th October 2018

1 Regulation (EU) No 650/2012 of the European Parliament and of the Council of 4 July 2012 on jurisdiction, applicable law, recognition and enforcement of decisions and acceptance and enforcement of authentic instruments in matters of succession and on the creation of a European Certificate of Succession (hereinafter Regulation, Succession Regulation) 
legal surrounding obligatory in the EU; after this two legal systems are examined in neighbouring countries in Central and Eastern Europe with different stages of development in the second and third segments by not only presenting but also comparing them.

The Succession Regulation shall be directly applicable in the Member States of European Union in accordance with the Treaties. There are several issues that fall outside the scope of the regulation, for example questions governed by the law of companies, such as clauses in the memorandum of association and articles of association of companies, which determine what will happen to the shares upon the death of the members.

The second part of the paper is about general rules in company law regarding inheritance of business shares. Different kinds of clauses in case of succession can be applied in the articles of associations in Austria, it is important to examine whether these can be used in Hungary.

In the third part we will discuss family firms as the smallest in our concentric circles. Writing about these is common in Austrian legal literature; in connection with then, succession in family firms is a significant topic. In Hungary it is not a widely-used expression regarding legal literature, but the usage and content of term "family firm" cannot be neglected because of their role in economy.

\section{THE SUCCESSION REGULATION}

"Inheritance law is not so necessary field of law from the aspect of unification of Europe without a doubt. Another field of law has this role, for example business law. Because of this, inheritance law was not a political issue for the legislator organs of the European Union. The economical and - if it is possible - the legal unity can only be realized in case, the differences between fields of law affected by economical concrescence disappear. One of these fields of law is inheritance law." ${ }^{2}$ The demand in connection with regulation of this field of law is not unsubstantiated: "the number of inheritance cases, which have cross-border feature in member states of member states of European Union, is estimated to 450000 per annum, and their combined value amounts to 120 billion euro." ${ }^{3}$ Based on the impact as-

2 Ludwig, I., Az öröklési kolliziós jog európai összehasonlító vizsgálata, Közjegyzők Közlönye, Vol. 8, Issue 7-8, 2004, p. 3

3 Mádl F.; Vékás L., Nemzetközi magánjog és nemzetközi gazdasági kapcsolatok joga, 8th edition, ELTE Eötvös Kiadó, Budapest, 2015, p. 400; Burandt, W.; Rojahn, D. (eds.) Erbrecht, 2nd edition, Verlag C. H. Beck oHG, München, 2014, p. 1431 
sessment report assembled to the draft of the Succession Regulation about " $10 \%$ of inheritance cases in the European Union have international feature". ${ }^{4}$

The direct force 5 which prevails in the view of the Regulation means that this Regulation did not have to be implemented to harmonise with Hungarian legal system, a contrario, the national law must follow it. The Act V of 2013 on Civil Code $^{6}$ has been created after accepting the Regulation; some procedural rules to issue the European Certificate of Succession are enacted into the Act XXXVIII of 2010 on probate actions. ${ }^{7}$

The Regulation is in force, ${ }^{8}$ most of its rules are to be applied from 17 August 2015, thus it must be applied concerning deaths on and following this day. Apart from the previous ones, several articles came into force earlier, for example several registries.

The applicable law by Article 20 of Succession Regulation is universal, in other words any law specified by this Regulation shall be applied whether or not it is the law of a member state. "This kind of resolution can be criticised, before all because applying a law beyond the Union is not justified by neither the aspects of internal market nor practical arguments." This thought is basically true, but the legislators wanted to create such conflict of law legislation rules so that law of that member state should be applied with which the testator has the (possibly) closest relation. The choice of law would be not so free, if the testator would be allowed to choose only between the laws of the Member States of European Union. It could be considerable that in case of choice of law the testator may choose law of such state, with which his/her heirs do not fare ill as if the applicable law by the Regulation would be followed. This method can be seen in the earlier Rome Regulations and in the Hague convention. ${ }^{10}$

4 COMMISSION STAFF WORKING DOCUMENT Accompanying the Proposal for a REGULATION OF THE EUROPEAN PARLIAMENT AND OF THE COUNCIL on jurisdiction, applicable law, recognition and enforcement of decisions and authentic instruments in matters of successions and on the introduction of a European Certificate of Inheritance, Impact Assessment, SEC(2009) 410 final, Brussels, 14. 10. 2009. [http://ec.europa.eu/civiljustice/news/docs/succession_impact_assessment_en.pdf] Accessed 16.04.2019. See also: Gothárdi E., Az általános joghatóság szabályozása az Európai Unió öröklési rendeletében, Magyar Jog, Vol. 62, Issue 9, 2015, pp. 522-523

5 Blutman, L., Az Európai Unió joga a gyakorlatban, 2nd edition, HVG-ORAC Lap- és Könyvkiadó Kft., Budapest, 2013, p. 338

6 [http://njt.hu/cgi_bin/njt_doc.cgi?docid=159096.357520] Accessed 16.04.2019

7 Act XXXVIII of 2010 Sections 102/B and 102/C. [http://njt.hu/cgi_bin/njt_doc.cgi?docid $=131478.361244]$ Accessed 16.04.2019

8 This Regulation shall enter into force on the twentieth day following that of its publication in the Official Journal of the European Union. (Article 84 Subsection 1) See also Article 84 Subsection 2

9 Mádl; Vékás, op. cit. note 2, p. 405

10 REGULATION (EC) No 593/2008 OF THE EUROPEAN PARLIAMENT AND OF THE COUNCIL of 17 June 2008 on the law applicable to contractual obligations (Rome I); REGULA- 
Unless otherwise provided for in the Regulation, the law applicable to the succession as a whole shall be the law of the state in which the deceased had his habitual residence ${ }^{11}$ at the time of death. Where, by way of exception, it is clear from all the circumstances of the case (for example because of work) that, at the time of death, the deceased was evidently more closely connected with a state other than the state whose law would be applicable as it was mentioned before, the law applicable to the succession shall be the law of that other state. ${ }^{12}$

"The Regulation accepts the theory of unity of heritage, in other words the legal fate of the estate is subsumed under law of one state"13 for reasons of legal certainty and in order to avoid the fragmentation of the succession, irrespective of the nature of the assets and regardless of whether the assets are located in another Member State or in a third state. ${ }^{14}$ This kind of regulation could be found also in the Hague convention ${ }^{15}$ The other theory created by the science of international private law is the so-called theory of division of heritage, where the applicable law is different in case of real estate (as a rule, the applicable law is the law of the location, lex loci) and in case of personal properties (the applicable law is the personal law of the deceased at the time of death, lex personae). ${ }^{16}$

The factors to determine the personal right of a legal person - principle of registration and principle of seat ${ }^{17}$ - are in connection with the issue above. These principles also determine the bases of inheritability of business shares; in other words the possibility to form the terms of the memorandum of association and the relevant cogent provisions, too. The unification of these principles would be a great benefit for the whole European Union; although there is only a slight chance to achieve this, due to the differences in opinions on which principle to follow.

TION (EC) No 864/2007 OF THE EUROPEAN PARLIAMENT AND OF THE COUNCIL of 11 July 2007 on the law applicable to non-contractual obligations (Rome II); COUNCIL REGULATION (EU) No 1259/2010 of 20 December 2010 implementing enhanced cooperation in the area of the law applicable to divorce and legal separation („Rome III”); The Hague Convention of 5 October 1961 on the Conflicts of Laws Relating to the Form of Testamentary Dispositions. See also: Bergquist, U.; Damascelli, D.; Frimston, R.; Lagarde, P.; Reinhartz, B.; Odersky, F., EU-Erbrechtsverordnung Kommentar, Verlag Dr. Otto Schmidt KG, Köln, 2015, pp. 128-129

11 In connection with habitual residence see further: ibid. pp. 34-35., pp. 68-70; Odersky, F., Die Europäische Erbrechtsverordnung in der Gestaltungspraxis, notar, Vol. 6, Issue 1, 2013, pp. 4-5

12 Article 21, see also Sections 23 to 25 of the Preamble

13 Mádl; Vékás, op. cit. note 2, p. 404. Szöcs, T., Az európai öröklési rendelet mint új kihivás, Közjegyzők Közlönye, Vol. 20, Issue 2, 2016, p. 34

14 Section 37 of the Preamble

15 See also: Bergquist et. al., op. cit. note 9, p. 33

16 Nagy, Cs. I., Nemzetközi magánjog, 2nd edition, HVG-ORAC Lap- és Könyvkiadó Kft., Budapest, 2012, p. 147

17 Ibid. pp. 62-65. Mádl, Vékás, op. cit. note 2, pp. 216-224 
The law determined pursuant to the law applied by the Regulation or the chosen law shall govern the succession as a whole, but the Regulation gives us a specific list also. In this part it mentions that the applicable law shall govern in particular among others the causes, time and place of the opening of the succession, disinheritance and disqualification by conduct, liability for the debts under the succession. ${ }^{18}$

One of the main questions of inheritance law after determination of beneficiaries ${ }^{19}$ is that how the rights and obligations are transferred to the successors. The Hungarian version of Regulation uses the word "átszállás" in this context. It has to be admitted that this is the correct translation of the expressions in the German and English version (der Übergang, transfer). This word was used in inheritance law in connection with inheritance of business shares in limited liability companies in Act IV of 2006, the previous Hungarian act on business associations. In this meaning the following definition was true without any restriction: the transfer of business share is a change in status, subject change of members not based on a legal transaction. ${ }^{20}$ Act IV of 2006 used this terminus technicus in connection with natural persons and legal persons, ${ }^{21}$ Act V of 2013 on Civil Code uses it only in case of transformation, merger and demerger of legal persons and subject change in business shares based on legal act. ${ }^{22}$

\section{a. The definition of succession in Succession Regulation}

The Regulation uses autonomic terminology, ${ }^{23}$ based on the previous decisions of the European Court $^{24}$ - and there is a definition for succession: ${ }^{25}$ the succession is no other, than succession to the estate of a deceased person and covers all forms of transfer of assets, rights and obligations by reason of death, whether by way of a voluntary transfer under a disposition of property upon death or a transfer

\footnotetext{
18 Article 23, see also Section 42 of the Preamble

19 Section 47 of the Preamble

20 Papp T. (ed.), Társasági jog, Lectum Kiadó, Szeged, 2011, pp. 412-413

$21 \quad$ Act IV of $2006 \$ 128$

22 Act $\mathrm{V}$ of $2013 \$ 3: 170$

23 Gombos, K., A jog érvényesülésének térsége az Európai Unióban, Wolters Kluwer Kft., Budapest, 2014 , p. 81

24 Case C-513/03 Héritiers de M. E. A. van Hilten-van der Heijden vs. Inspecteur van de Belastingdienst [2006] ECLI:EU:C:2006:131, par. 41.; Case C-256/06 Theodor Jäger vs. Finanzamt Kusel-Landstuhl [2008] ECLI:EU:C:2008:20, par. 25.; Case C-11/07 Hans Eckelkamp \& Co. vs. Belgische Staat (2008) ECLI:EU:C:2008:489, par. 39; Case C-25/10 Missionswerk Werner Heukelbach eV vs. État belge [2011] ECLI:EU:C:2011:65, par. 16.; Case C-132/10 Olivier Halley \& Co. vs. Belgische Staat [2011] ECLI:EU:C:2011:586, par. 19.; Case C-31/11 Marianne Scheunemann vs. Finanzamt Bremerhaven [2011] ECLI:EU:C:2012:481, par. 22

25 Article 3 Subsection 1 a)
} 
through intestate succession. We can find similar components in the preamble, placing it into the Regulation it became full value legal norm. According to the Section 47 of the Preamble the law applicable to the succession should determine who the beneficiaries are in any given succession, these are determined, so it covers heirs and legatees and persons entitled to a reserved share. Obviously it was the purpose of the legislative body to cover all the hereditary relationship, so this category must be understood under the scope of the Regulation.

The Case Marianne Scheunemann vs. Finanzamt Bremerhaven ${ }^{26}$ is in connection with inheritance tax exemption, and it has a close relationship to company law. The reference has been made in proceedings between Mrs Scheunemann and Finanzamt Bremerhaven (Bremerhaven Tax Office; 'the Finanzamt') concerning the notice relating to the calculation of inheritance tax on an estate which includes a shareholding in a capital company established in a third country. By its question, the referring court asks in essence whether the Treaty provisions on the free movement of capital are to be interpreted as precluding legislation of a Member State which, for the purposes of the calculation of inheritance tax, excludes the application of certain tax advantages to an estate in the form of a shareholding in a capital company established in a third country, while conferring those advantages in the event of the inheritance of such a shareholding when the registered office of the company is in a Member State. Under German law, the tax-free amount and the reduced-rate valuation shall apply to shares in a capital company where the capital company has its registered office or principal place of business in Germany at the time when the tax is incurred and the testator or donor had a direct holding in the nominal capital of that company amounting to more than one quarter thereof. According to the German Government, one of the aims of the tax advantages provided for under the national provisions at issue in the main proceedings is to encourage persons inheriting substantial shareholdings in a company to become involved in its management so as to be able ultimately to ensure the survival of the undertaking and save jobs. As regards the facts in the case before the referring court, it is established that the testator had a $100 \%$ holding in the capital of the company concerned and, accordingly, it cannot be denied that he was able to exert a definite influence over its decisions and to determine its activities, although this case is different because of the Canadian seat of the company. Legislation of a Member State, which, for the purposes of the calculation of inheritance tax, excludes the application of certain tax advantages to an estate in the form of a shareholding in a capital company established in a third country, while conferring those advantages in the event of the inheritance of such a shareholding when the regis-

26 Case C-31/11 Marianne Scheunemann vs. Finanzamt Bremerhaven [2011] ECLI:EU:C:2012:481, par. 22 
tered office of the company is in a Member State, primarily affects the exercise of the freedom of establishment, since that holding enables the shareholder to exert a definite influence over the decisions of that company and to determine its activities. Those Treaty provisions are not intended to apply to a situation concerning a shareholding held in a company which has its registered office in a third country. We can agree with the opinion of the Court because the seat of the company is not in a Member State of the European Union, so none of the freedoms is violated, if such restrictive rules (in this case rules of not giving a tax exemption) are valid and these do not affect third state.

Apart from the definition of succession the Regulation does not determine the definition of legacy, but that opinion is acceptable so this shortage will not cause any problem during application of the Regulation. ${ }^{27}$

\section{b. The connection between company law and the Regulation}

Questions governed by the law of companies and other bodies, corporate or unincorporated, such as clauses in the memorandum of association and articles of association of companies and other bodies, corporate or unincorporated, which determine what will happen to the shares upon the death of the members, ${ }^{28}$ is excluded from the scope of this Regulation. This exception means the Hungarian legislative body does not have to do anything to adjust the laws to this Regulation in subject of company law, the actual national regulation is proper. This topic is also excluded from the scope of the Regulation from the point of view of Hungarian law, because to decide the possibility of inheritance of business shares in every type of companies, whether there are any limitations, is not an inheritance law, but a company law matter. ${ }^{29}$

Because of the above mentioned, to decide if a legal matter is to be governed by company law or inheritance law, the law of competent court in succession with cross-border implications will decide, and Article 30 of Succession Regulation must be applied: Where the law of the State in which certain immovable property, certain enterprises or other special categories of assets are located contains special rules which, for economic, family or social considerations, impose restrictions concerning or affecting the succession in respect of those assets, those special rules shall apply to the succession in so far as, under the law of that state, they are applicable irrespective of the law applicable to the succession. ${ }^{30}$

\footnotetext{
$27 \quad$ Bergquist et. al., op. cit. note 9, p. 64

28 Article 1 Subsection $2 \mathrm{~h}$ )

29 Mádl; Vékás, op. cit. note 2, p. 404

30 Section 54 of the Preamble. Bergquist et. al., op. cit. note 9, p. 53
} 


\section{General rules in company law regarding inheritance of business shares}

In Hungarian law at general partnerships and limited partnerships the heir of the deceased person can join to these partnerships based on the agreement with the other living members. This shows the partnership feature of these companies, because for the members, who are still in the partnership, it is not irrelevant who enters into the company in the place of the deceased, the membership is bound to persons. ${ }^{31}$ The heir who becomes member must not fulfil contribution, only in case the company and the heir agreed in that way. ${ }^{32}$ Not only the declaration of the heir is needed as soon as possible, but the unanimous consent of the other members. ${ }^{33}$ If these are not fulfilled it is possible that a two-personnel general partnership or a limited partnership which has only one acting partner and one limited partner is terminated, due to the fact that the legitimate functioning cannot be restored six months after the death of a member with entering other person into the company. ${ }^{34}$

In case of limited liability companies, it also depends on the will of the heirs whether they would like to continue the activity of their predecessor, in the event of a member's death, the heir may request the managing director to be entered in the register of members upon providing proof of inheritance. ${ }^{3536}$ The identity of the heir is also needed to be proven unambiguously. For the unification of this question the European Certificate of Succession was created, although the use of this Certificate shall not be mandatory, ${ }^{37}$ it is practical. A European Certificate of Succession may be requested - with the exception set out below - after the grant of probate of full effect, the temporary grant of probate declared fully enforceable, or the ruling on the conclusion of the probate proceedings where the court adjudicates all claims affected by the temporary grant of probate becomes final. The executor of the will provided for in Regulation and the administrator of the estate - including the guardian ad litem provided for business shares and claim may apply for the issue of a European Certificate of Succession before the specified time in order to demonstrate the powers referred to in Article 63(2)c) of the Regulation. "A whole chapter of the Regulation (articles 62 to 73) has been dedicated

\footnotetext{
31 Kisfaludi A., Szabó M., (eds.) A gazdasági társaságok nagy kézikönyve, Complex Kiadó, Budapest, 2008, p. 759

$32 \quad$ Act $\mathrm{V}$ of $2013 \$ 3: 149 ., \$ 3: 155$

33 Papp, op. cit. note 19, p. 386

$34 \quad$ Act $\mathrm{V}$ of $2013 \$ 3: 152$., $\$ 3: 158$

35 Kisfaludi, Szabó op. cit. note 29, p. 944

$36 \quad$ Act $\mathrm{V}$ of $2013 \$ 3: 170$

37 Article 62 Subsection 2

38 Act XXXVIII of $2010 \$ 102 / B$. Subsections 1 and 2
} 
exclusively to the Certificate. Thus, the European Certificate of Succession might be called a third pillar of the Succession Regulation - besides the rules on the applicable law and on jurisdiction, recognition and enforcement." ${ }^{39}$ The form of the application and the Certificate is in the $4^{\text {th }}$ and $5^{\text {th }}$ annex of Commission Implementing Regulation (EU) No 1329/2014 of 9 December 2014, ${ }^{40}$ this regulation executes the Succession Regulation.

The Certificate ${ }^{41}$ was created in order to facilitate the proving of the heirs', legatees', executors' of the will or administrators' of the estate rights and status in another Member State, for instance in a Member State in which succession property is located, in case of a succession with cross-border implications within the Union, to settle the case speedily, smoothly and efficiently. In order to respect the principle of subsidiarity, the Certificate should not prevail over internal documents which may exist for similar purposes in the Member States. ${ }^{42}$ It should not be an enforceable title in its own right but should be considered as a document of evidentiary effect. Furthermore, it should be presumed authentically certify facts which have been established under the law applicable to the succession or under any other law applicable to specific facts, such as the substantive validity of dispositions of property upon death. ${ }^{43}$

The managing director may refuse to register the heir or the successor if the persons authorized in the memorandum of association provide a statement on the acquisition of the business share according to the conditions laid down in the memorandum of association within a preclusive period of 30 days from the date of the heir's or successor's application for registration taking effect, and the market value of the business share is paid by such persons to the heir or successor. Any clause of the memorandum of association to provide a longer term than 30 therefore days shall be null and void. ${ }^{44}$

The shares incorporate membership rights in private limited companies; these are securities with a really special hereditary, company, security legal relationship. In

39 Hertel, Ch. European Certificate of Succession - content, issue and effects. ERA Forum. Journal of the Academy of European Law, Vol. 15, Issue 3, 2014, p. 394

40 COMMISSION IMPLEMENTING REGULATION (EU) No 1329/2014 of 9 December 2014 establishing the Forms referred to in Regulation (EU) No 650/2012 of the European Parliament and of the Council on jurisdiction, applicable law, recognition and enforcement of decisions and acceptance and enforcement of authentic instruments in matters of succession and on the creation of a European Certificate of Succession

41 For further analysis of the Certificate see ibid pp. 397-406

42 Section 67 of the Preamble

43 See also Section 71 of the Preamble

$44 \quad$ Act $V$ of $2013 \$ 3: 170$. Subsection 2 
connection with these, the problem mentioned before does not arise in case their transferability is not restricted.

Company law is also excluded from the scope of other conflicting legislation regulations, such as Rome-I Regulation. The inheritance of business shares, origin of claim for redemption will be regulated in the memorandum of associations; along with the issues of continuing business activity and becoming a member of the company. The conflict of laws rules of each state will regulate the judgment of memorandum of associations. ${ }^{45}$

According to Tamás Gyekiczky: „it is unclear, whether the cases in which the memorandum of associations have accurately detailed provisions in connection with the inheritance of the members' business shares belong to the scope of the regulation or only those cases are excluded from the scope where the member's death results to succession in the company regulated by the memorandum of association and company law. The Regulation supports the second interpretation; this is confirmed by definition of inheritance." ${ }^{46}$ Our point of view by the interpretation of the text is that the scope of the Regulation is also excluded if the memorandum of association has detailed provisions for case of one member's death. As per the Regulation: such clauses in the memorandum of association are also excluded from the scope of the Regulation, which determine what will happen to the shares upon the death of the members. ${ }^{47}$ This determination could be understood as inheritance, too. Although the definition for succession in the Regulation would like to cover all kind of devolution of rights and duties, however company law prevails over the rules of inheritance law, the Regulation took this into consideration and this way it excluded business shares from the scope.

Nowadays it could easily happen that one company has members from another country. If these members are natural persons, in case of their death the Regulation shall be applied. With respect to the fact that company law is excluded from the scope, the devolution is based on the memorandum of association and on the law, and the applicable law by the Regulation determines who the heir is, in other words, who is allowed to become a member in the company by right of inheritance, unless the memorandum of association provides otherwise.

In Austrian company law general partnerships are dissolved in the event of death of a member. This is because the law has the starting point if a member dies, who is liable for debts which are not covered with the assets of the company, the other

\footnotetext{
45 Burandt; Rojahn op. cit. note2, p. 1434

46 Gyekiczky T., Az európai „öröklési” rendeletröl, Európai Jog Vol. 24, Issue 2, 2014, pp. 2-3

47 Article 1 Subsection $2 \mathrm{~h}$
} 
members do not want to continue the activity of the company. The members of family firms plan to operate the company for a long time, through several generations; if they do not want it to dissolve in case of the death of a member, they have to state this regulation in the memorandum of association. ${ }^{48}$

With respect to the fact that the heirs are not known until the member' death, the memorandum of associations does not have to name this person; it must only contain the opportunity of succession. The living members also can decide to continue the activity of the company. ${ }^{49}$

The Austrian limited partnerships have almost the same regulation as general partnerships because unless otherwise prescribed, rules of general partnerships ${ }^{50}$ have to be applied for limited partnerships. The general partner's death dissolves the company, but the limited partner's death does not, so his/her contribution can be inherited. This article is dispositive; ${ }^{51}$ because of this the memorandum of association can allow the dissolution of company in case of the limited partner's death.

There are four different clauses; they can be settled in the memorandum of association of both general partnerships and limited partnerships: ${ }^{52}$

1. Proceeding clause (Fortsetzungsklausel): the living members agree on continuing the business activity, if one of the members dies. The heirs are neither allowed nor obliged to become members; the contribution is redemption in the legacy. ${ }^{53}$

2. Succession clause (Nachfolgeklausel): the heirs are allowed to become members, so the company is not dissolved, and there is no redemption. ${ }^{54}$

3. Qualified succession clause (Qualifizierte Nachfolgeklausel): there is an accurately determined person in the memorandum of association who is allowed to enter into the company, if a member dies. This person has to meet certain requirements; the new member can be for example an employee of the company, or another person, it is also possible that the heir is the member. Those heirs, who are not allowed to join to the company, are entitled to redemption. ${ }^{55}$

\footnotetext{
48 Kalss, S., Probst, S. Familienunternehmen. Manzsche Verlags- und Universitätsbuchhandlung, Wien, 2013, p. 212, ibid p. 661

49 Unternehmensgesetzbuch $\$ 141$ (1)

50 Unternehmensgesetzbuch $\$ 161(2)$

51 Kalss, Probst op. cit. note 45, pp. 215-216

$52 \quad$ Ibid. p. 661

$53 \quad$ Ibid. pp. 662-663

54 Ibid. pp. 663-664

$55 \quad$ Ibid. pp. 664-665
} 
4. Entry clause (Eintrittsklausel): a third person can join to the company, who was not a member until the death of the deceased person, but he/she is not obliged to do so. ${ }^{56}$

At Austrian limited liability companies and private limited companies the business shares and securities are inheritable. Based on Art. 75 of the Act on Limited Liability Companies members have business shares, and in the next article it declares that business shares are inheritable ${ }^{57}$ without any further explanations, because it also says that business shares are transferable, ${ }^{58}$ and rest of this article is about transfer. Upon this, the business shares do not dissolve in case of death of a member, and compared to general partnerships and limited partnerships it is not possible to exclude the inheritance of business shares. Private limited companies have the same regulation as limited liability companies, securities are parts of the estate. ${ }^{59}$

\section{Family firms inheritability of shares in family firms}

The aim of the regulation of company law is to coordinate the different interests of members of company, to guarantee balance between them, while the most important goal of inheritance law is to distribute the estate of the deceased person. Since companies are established vitally for a longer period, members would like to regulate succession. ${ }^{60}$ The heirs want to acquire the inheritance and dispose of it, the company would like a proper decision-making and management, the members want power and profit. ${ }^{61}$ All of these interests have to be conciliated.

In Hungary there is no legal definition for family firms, although the term "family business" is used in legal practice ${ }^{62}$ without giving any hints about its precise content. The question is how courts interpret "family", and whether Austrian solutions can be used in Hungary.

In the Austrian and German legal literature one can find several scientific articles on family firms, as a possible type of company. Compared to "traditional" com-

\footnotetext{
$56 \quad$ Ibid. p. 665

57 Brünner, G.; Pasrucker, Ch., Die GmbH von der Gründung bis zur Auflösung, 2. Auflage, dbv-Verlag, Graz - Wien, 2016, p. 95

58 GmbHG $\$ 76$ (1) Die Geschäftsanteile sind übertragbar und vererblich

59 Kalss; Probst op. cit. note 45, p. 671, Kalss, S., Die Vererbung von Aktien, Journal für Erbrecht und Vermögensnachfolge, Vol. 9, Issue 4, 2015, pp. 112-119

60 Kalss, Probst, ibid., p. 654, Czernich, D.; Guggenberger, B.; Schwarz, M. (ed.) Handbuch des österreichischen Familienunternehmens. LexisNexis Verlag, Wien, 2005, p. 345

${ }_{61}$ Kalss; Probst op. cit. note 45, p. 655., Probst, S., Erbrechtsnovelle 2014 aus dem Blickwinkel der Erhaltung der österreichischen Unternehmen. Die Wirtschaftstreuhänder Issue 5-6., 2014, p. 341

62 FIT-H-PJ-2014-284.; BDT 2005. 1288.; ÍH 2009. 130
} 
panies, there are differences in connection with members, since they are members of in almost most cases the same family, and they have different aims in a certain way. Their purpose is not only making large profits but also to save the fortune of the family and to ensure them financial care. ${ }^{63}$ These companies have sometimes fewer members than other companies. ${ }^{64}$

We do not find legal definition in Austria, there are different definitions laid down in legal literature. Certain companies are named after the family and maximum three family members have at least $50 \%$ of the votes; in other family firms they do not have only at least $50 \%$ of the votes, but they also manage the company. ${ }^{65}$ These are objective criteria, but there are subjective requirements, just as the mentioned will to continue the activity of the company through several generations. ${ }^{66}$ Family firms can have members from different families and there could be members in a family firm, who are not members of the dominant family. ${ }^{67}$ It might be surprising, but it is also possible that a family firm is a one-man business enterprise. ${ }^{68}$ In my opinion, the acceptance of this Austrian legal and economical analysis in Hungary does not mean strange result, this kind of definitions would be proper.

In Hungary there is no legal definition for family firms, although the term "family business" is used in legal practice without giving any hints about its precise content. The question is how courts interpret "family", and whether Austrian solutions can be used in Hungary.

We hardly find any scientific articles and references in Hungarian literature to answer this question. In legal practice, family firms have the same company types what we find in Hungarian Civil Code, they are widely ranged, approximately $70 \%$ of the Hungarian companies are controlled by families, they produce nearly $50 \%$ of the GDP and they employ about $50 \%$ of the employees. The generationchange is a large challenge for them, on the other hand, they do not have finished plans for succession so during changes of generation nearly two thirds of them dissolve. ${ }^{69}$

63 Kalss; Probst op. cit. note 45, p. 2., ibid p. 16

64 LeMar, B. Generations- und Führungswechsel im Familienunternehmen. 2. Auflage, Springer Fachmedien, Wiesbaden, 2014, p. 6

65 Kalss; Probst op. cit. note 45, pp. 9-12

$66 \quad$ Ibid. p. 17

67 Ibid. p. 77

68 Ibid. pp. 12-13., ibid p. 191

69 Cs. K., Optimisták a családi cégek, 2016. [http://www.vg.hu/kkv/optimistak-a-csaladi-cegek-475310]. Accessed 27.08.2018 
The legal status of family firms is special in that way, although there is no proper legal definition for them, but this expression is used in legal practice and everyday life. It cannot be understood completely why there are no any further legal consequences or results if the court establishes the fact that the company is a family firm. Based on the Austrian legal literature, a coherent and not too casuistic definition should be created, and if a legal person meets these requirements, it should get several discounts.

This definition must have a proper unit, what "family" means. I believe the term 'relative ${ }^{70}$ in Closing Provisions in Hungarian Civil Code is not enough, Section 4:96 would be more proper for it. ${ }^{71}$ In order to determine more accurately these persons and to avoid not knowing who a family member is, because they hardly know each other, provisions of inheritance law should be used. This circle should be circumscribed in that way that only the deceased member's great-grandparents and all of their descendants should be understood as 'family'.

In Hungarian, the term 'family firm' is equal to 'family business' („családi vállalkozás”). 'Business' („vállalkozás”) is equal to 'business party' (in term of the Hungarian law system) that means any person acting for purposes which are not outside his trade, business or profession. We have to call attention to the fact that family firm (family business) are not only some kind of distinguished parties in connection with consumer contracts. For this purpose, the Hungarian version of 'family firm' ('családi cég') can be used. This is more proper because firms are such legal persons, their certain aspects regulated in Act V of 2006 on Public Company Information, Company Registration and Winding-up Proceedings, as their aims of most of those could be both profit and durable operating, and both capital consolidation and partnership features can be strong.

All of these should have effects on succession in companies: in respect of the possibility of succession, if there is any special point, the living members of the family who are also members in the company would have priority to get the deceased member's contribution; irrespective of the fact that they are not the heirs. In order

70 Act V of 2013 Section 8:1 (1) For the purposes of this Act:

1. 'close relative' shall mean spouses, next of kin, adopted children, stepchildren, foster children, adoptive parents, stepparents, foster parents, and siblings;

2 'relative' shall mean close relatives, domestic partners, spouses of the next of kin, spouse's next of kin and siblings, and spouses of siblings

71 Act V of 2013 Section 4:96 [Family relationship]

(1) Lineal descent refers to a blood relative in the direct line of descent.

(2) Collateral descent refers to relatives not in direct line of descent, having at least one common ancestor. 
to make a legal definition for family firms, it must have another aims, such as tax relief.

\section{CONCLUSIONS}

The creation of the Regulation was necessary with respect to the inheritance matters having cross-border implications; the aim of the Regulation was to cover all of these legal relations that are possible from the aspect of conflicting legislation and international civil procedure, and tried to pay attention to every situation that may arise from the different solutions of the Member States.

Although the material scope of the Regulation does not include certain aspects of company law, even if they are relevant from the aspect of inheritance law, the examination of excluding rules are necessary to determine their expanse.

The Hungarian and Austrian company law have a lot of common points, but some crucial differences as well. On the other hand, Austrian law allows certain solutions and with those the Hungarian regulation can be reached, this shows that the two legal systems in this field if law can converge, and Hungarian legal literature should pay attention on Austrian scientific articles in connection with family firms. Scholars must create a dogmatically coherent system to set place of family firms, so legislators can lay down different preferences for them. With these preferences, people are more likely to establish family firms, so they can help families to earn for their living.

\section{REFERENCES}

\section{BOOKS AND ARTICLES}

1. Bergquist, U.; Damascelli, D.; Frimston, R.; Lagarde, P.; Reinhartz, B.; Odersky, F., EUErbrechtsverordnung Kommentar, Verlag Dr. Otto Schmidt KG, Köln, 2015

2. Blutman, L., Az Európai Unió joga a gyakorlatban, 2nd edition, HVG-ORAC Lap- és Könyvkiadó Kft., Budapest, 2013

3. Brünner, G.; Pasrucker, Ch., Die GmbH von der Gründung bis zur Aufösung, 2. Auflage, dbv-Verlag, Graz - Wien, 2016

4. Burandt, W.; Rojahn, D. (eds.) Erbrecht, 2nd edition, Verlag C. H. Beck oHG, München, 2014

5. Czernich, D.; Guggenberger, B.; Schwarz, M. (eds.) Handbuch des österreichischen Familienunternehmens. LexisNexis Verlag, Wien, 2005

6. Gombos, K., A jog érvényesülésének térsége az Európai Unióban, Wolters Kluwer Kft., Budapest, 2014 
7. Gothárdi E., Az általános joghatóság szabályozása az Európai Unió öröklési rendeletében, Magyar Jog, Vol. 62, Issue 9, 2015

8. Gyekiczky T., Az európai „öröklési” rendeletröl, Európai Jog Vol. 24, Issue 2, 2014

9. Hertel, Ch. European Certificate of Succession - content, issue and effects. ERA Forum. Journal of the Academy of European Law Vol. 15, Issue 3, 2014

10. Kalss, S., Die Vererbung von Aktien, Journal für Erbrecht und Vermögensnachfolge, Vol. 9, Issue 4, 2015

11. Kalss, S., Probst, S. Familienunternehmen. Manzsche Verlags- und Universitätsbuchhandlung, Wien, 2013

12. Kisfaludi A.; Szabó M., (eds.) A gazdasági társaságok nagy kézikönyve, Complex Kiadó, Budapest, 2008

13. LeMar, B. Generations- und Führungswechsel im Familienunternehmen. 2. Auflage, Springer Fachmedien, Wiesbaden, 2014

14. Ludwig, I., Az öröklési kolliziós jog európai összehasonlitó vizsgálata, Közjegyzők Közlönye, Vol. 8, Issue 7-8, 2004

15. Mádl F.; Vékás L., Nemzetközi magánjog és nemzetközi gazdasági kapcsolatok joga, 8th edition, ELTE Eötvös Kiadó, Budapest, 2015

16. Nagy, Cs. I., Nemzetközi magánjog, 2nd edition, HVG-ORAC Lap- és Könyvkiadó Kft., Budapest, 2012

17. Odersky, F., Die Europäische Erbrechtsverordnung in der Gestaltungspraxis, notar, Vol. 6, Issue 1, 2013

18. Papp T. (ed.), Társasági jog, Lectum Kiadó, Szeged, 2011

19. Probst, S., Erbrechtsnovelle 2014 aus dem Blickwinkel der Erhaltung der österreichischen Unternehmen. Die Wirtschaftstreuhänder Issue 5-6., 2014

20. Szőcs, T., Az európai öröklési rendelet mint új kihivás, Közjegyzők Közlönye, Vol. 20, Issue 2, 2016

\section{COURT OF JUSTICE OF THE EUROPEAN UNION}

1. Case C-513/03 Héritiers de M. E. A. van Hilten-van der Heijden vs. Inspecteur van de Belastingdienst [2006] ECLI:EU:C:2006:131

2. Case C-256/06 Theodor Jäger vs. Finanzamt Kusel-Landstuhl [2008] ECLI:EU:C:2008:20

3. Case C-11/07 Hans Eckelkamp \& Co. vs. Belgische Staat (2008) ECLI:EU:C:2008:489

4. Case C-25/10 Missionswerk Werner Heukelbach eV vs. Etat belge [2011] ECLI:EU:C:2011:65

5. Case C-132/10 Olivier Halley \& Co. vs. Belgische Staat [2011] ECLI:EU:C:2011:586

6. Case C-31/11 Marianne Scheunemann vs. Finanzamt Bremerhaven [2011] ECLI:EU:C:2012:481

\section{EU LAW}

1. Regulation (EU) No 650/2012 of the European Parliament and of the Council of 4 July 2012 on jurisdiction, applicable law, recognition and enforcement of decisions and accep- 
tance and enforcement of authentic instruments in matters of succession and on the creation of a European Certificate of Succession [2012] OJ L 201, 27.7.2012

2. Commission Implementing Regulation (EU) No 1329/2014 of 9 December 2014 establishing the Forms referred to in Regulation (EU) No 650/2012 of the European Parliament and of the Council on jurisdiction, applicable law, recognition and enforcement of decisions and acceptance and enforcement of authentic instruments in matters of succession and on the creation of a European Certificate of Succession [2014] OJ L 359, 16.12.2014

3. Regulation (EC) No 593/2008 of the European Parliament and of the Council of 17 June 2008 on the law applicable to contractual obligations (Rome I) [2008] OJ L 177, 4.7.2008

4. Regulation (EC) No 864/2007 of the European Parliament and of the Council of 11 July 2007 on the law applicable to non-contractual obligations (Rome II) [2007] OJ L 199, 31.7.2007

5. Council Regulation (EU) No 1259/2010 of 20 December 2010 implementing enhanced cooperation in the area of the law applicable to divorce and legal separation („Rome III”) [2010] OJ L 343, 29.12.2010

\section{LIST OF NATIONAL REGULATIONS, ACTS AND COURT DECISIONS}

1. Act IV of 2006 on business associations (not in force) $(\mathrm{H})$

2. Act V of 2006 on Public Company Information, Company Registration and Windingup Proceedings $(\mathrm{H})$ [http://njt.hu/cgi_bin/njt_doc.cgi?docid=101684.361233] Accessed 16.04.2019

3. Act XXXVIII of 2010 on probate actions (H) [http://njt.hu/cgi_bin/njt_doc. cgi?docid=131478.361244] Accessed 16.04.2019

4. Act V of 2013 on Civil Code (H) [http://njt.hu/cgi_bin/njt_doc.cgi?docid=159096.357520] Accessed 16.04.2019

5. Bundesgesetz über besondere zivilrechtliche Vorschriften für Unternehmen (Unternehmensgesetzbuch - UGB) (A) [https://www.ris.bka.gv.at/GeltendeFassung.wxe?Abfrage=Bund esnormen\&Gesetzesnummer=10001702] Accessed 16.04.2019

6. Gesetz vom 6. März 1906, über Gesellschaften mit beschränkter Haftung (GmbH-Gesetz - GmbHG) (A) [https://www.ris.bka.gv.at/GeltendeFassung.wxe?Abfrage=Bundesnormen \&Gesetzesnummer=10001720] Accessed 16.04.2019

7. BDT 2005. 1288. (H) (Collection of Judicial Decisions)

8. FIT-H-PJ-2014-284. (Decision of Court of Appeal of Budapest) (H)

9. ÍH 2009. 130. (H) (Decisions of Court of Appeals)

\section{WEBSITE REFERENCES}

1. Cs. K., Optimisták a családi cégek, 2016. [http://www.vg.hu/kkv/optimistak-a-csaladi-cegek-475310] Accessed 27.08.2018

2. Convention of 5 October 1961 on the Conflicts of Laws Relating to the Form of Testamentary Dispositions [https://www.hcch.net/en/instruments/conventions/full-text/?cid=40] Accessed 16.04.2019 